\title{
Antifungal activity of crude extracts of stem-bark of Acacia ampliceps Maslin. (Family Leguminosae)
}

\author{
Fatima*, Muhammad Saleem Khan, Maqsood Anwar, Sidra Rahman and \\ Muhammad Anwar Sajad \\ Department of Botany, Islamia College Peshawar-Pakistan \\ *Corresponding author's email: fatimaimtiaz535@gmail.com \\ Citation \\ Fatima*, Muhammad Saleem Khan, Maqsood Anwar, Sidra Rahman and Muhammad Anwar Sajad. Antifungal \\ activity of crude extracts of stem-bark of Acacia ampliceps Maslin (Family Leguminosae). Pure and Applied \\ Biology. Vol. 8, Issue 2, pp1690-1697. http://dx.doi.org/10.19045/bspab.2019.80112
}

\begin{tabular}{llll}
\hline \hline Received: 25/03/2019 & Revised: 21/06/2019 & Accepted: 26/06/2019 & Online First: 29/06/2019 \\
\hline
\end{tabular}

\section{Abstract}

The present study explains antifungal activity of crude extracts of stem-bark of Acacia ampliceps Maslin (Family Leguminosae). Two different extracts of the stem-bark of this plant were used against four fungal strains. It was revealed that methanol extract was comparatively inhibitorier to all fungal strains than ethanol. Methanol extract showed significant inhibition against Trichoderma spp., fair inhibition against Rhizopus and Acremonium spp. and less activity against Aspergillus niger. However, ethanol extract showed comparatively high activity against Trichoderma spp. while the remaining three fungal strains were comparatively resistant to it. Maximum zone of inhibition was recorded to be $22 \mathrm{~mm}$ by methanol extract at $1000 \mu \mathrm{g} / \mathrm{mL}$ against Trichoderma spp. Keywords: Acacia ampliceps; Crude extract; Fungal strains; Medicinal plants; Zone of inhibition

\section{Introduction}

Acacia ampliceps belongs to family Mimosaceae (Leguminosae) is a shrub of 2-8 $m$ height. It has 1-4 stems branches arise from the ground level having yellow color twigs with yellowish-green or brown-green, spreading canopy. It is native to the Northern parts of Western Australia. The plant is cultivated in different parts of Pakistan for medicinal, ornamental and economic purposes. Medicinal plants (MP) are traditionally used for the treatment of various human ailments. In different countries, plants are used as prospective source of antimicrobial agents [1]. About 60 to $90 \%$ populations of the developing countries use plant-derived medicines. Traditionally, crude plant extracts (CPE) are used as herbal medicine for the treatment of various human infectious diseases [1-3]. Medicinal plants are rich in a variety of phytochemicals such as alkaloids, glycosides, flavonoids, terpenoids, tannins and phenolic compounds which have been found in vitro to have antimicrobial properties [4-6].

Indeed plants possess a wide variety of bioactive molecules, which make them a rich home of different brands of medicines. Higher plants, as sources for remedial compounds, have sustained to perform a leading role in the maintenance of human health since ancient times [7]. Acacia spp. 
possess secondary metabolites like alkaloids, cyanogenic glycosides, amines, terpenes, saponins, hydrolysable tannins, condensed tannins, flavonoids, cyclitols, fluoroacetate, non-protein amino acids, gums, fatty acids, seed oils, essential oils, sterols and genins [8]. Acacia ampliceps is one of precious medicinal plant species which exhibit antimicrobial (antifungal) potential due to presence of variety of phytochemicals compounds in it. The present study aimed to investigate the antifungal activity of ethanol and methanol extract of Acacia ampliceps Maslin stem-bark against four fungal strains.

\section{Materials and methods}

\section{Plant collection and identification}

Disease free stem-bark of Acacia ampliceps was collected from the Pakistan Forest Institute, Peshawar. It was identified with the help of available literature and then confirmed [9]. After identification the plant is then deposited in herbarium of Botany department, Islamia College Peshawar for future references.

\section{Preparation of crude extract}

The stem-bark was sliced into small parts and thoroughly washed with tap water to remove dust and dirt. In order to avoid the evaporation of volatile oils and chemicals, the stem-bark was dried in shade for 15 to 25 days. The dried stem-bark was ground through mechanical grinder to get fine powder. $100 \mathrm{~g}$ powder was soaked in $600 \mathrm{~mL}$ methanol and in $600 \mathrm{~mL}$ ethanol for 21 days. Both solutions were filtered using Wattman filter paper No.1 in separate beakers and concentrated under reduced pressure at $45^{\circ} \mathrm{C}$ in rotary evaporator. Then both extracts were shifted to separate china dishes and further dried in Water bath at $55^{\circ} \mathrm{C}$ to obtain crude extracts. Finally methanol and ethanol crude extracts were stored in $18 \mathrm{~g}$ and $14 \mathrm{~g}$ viles respectively [10].These extracts were preserved in refrigerator at $4^{\circ} \mathrm{C}$ to prevent contamination and processed for antifungal activity.

\section{Antifungal activity}

Both extracts were tested for its antimicrobial activity (antifungal) by agar well diffusion method $[11,12]$ with slight modification.

\section{Preparation of stock solution and working dilution}

For the preparation of stock solution 1000 $\mu \mathrm{g} / \mathrm{mL}, 20 \mathrm{mg}$ of crude extracts (both methanol and ethanol) was dissolved in $2 \mathrm{~mL}$ DMSO (Dimethyl sulfoxide) in a test tube and shaked well via Vortex mixture. This solution was then shifted to Eppendorf tube. Working solution $(5 \mathrm{mg} / \mathrm{mL})$ was made by mixing $500 \mu \mathrm{g} / \mathrm{mL}$ of stock solution with equal volume of DMSO.

\section{Standard control}

In case of antifungal bioassay, $0.05 \%$ Nystatin (25ml/cc and 75ml/cc DMSO) was used as positive control and $500 \mu \mathrm{g} / \mathrm{mL}$ DMSO was used as negative control.

\section{Test fungal strains used}

Four different strains of fungi were taken from the laboratory of Department of Botany Islamia College Peshawar. These were Acremonium spp., Aspergillus niger, Rhizopus spp. and Trichoderma spp.

\section{Media preparation}

Potato Dextrose Agar (PDA) was used for culturing of fungal strains. About $9.75 \mathrm{~g}$ Potato Dextrose Agar (PDA) was dissolved in $300 \mathrm{ml}$ of distilled water and then mixed with the help of Thermo-Magnetic Stirrer and poured in autoclavable bottle and sterilized in autoclave at $121^{\circ} \mathrm{C}$ for 15 minutes under high pressure.

\section{Inoculation and antifungal bioassay}

Fungal strains were streaked on media plates using sterile cotton swabs and then incubated for a day. Potato Dextrose Agar (PDA) was poured in two sets (one set for one extract) of four sterile petri dishes in laminar hood. After about 15 minutes, the media changed into a jelly-like substance. Four wells were bored via a sterile cork borer of $5 \mathrm{~mm}$ at equal distance from each other. To these wells, $1000 \mu \mathrm{g} / \mathrm{mL}$ extract stock solution, 500 
$\mu \mathrm{g} / \mathrm{mL}$ working dilution, positive control and negative control were added separately via micropipette and zone of inhibition (ZOI) were measured by using ruler in millimeter $(\mathrm{mm})$ in diameter around the wells from the bottom of the plates.

\section{Results}

Results revealed that methanol extract showed comparatively high activity against Trichoderma while rest of the three fungal strains were comparatively resistant to it. On the other hand, methanol extract significant inhibition against Trichoderma spp., fair inhibition against Rhizopus and Acremonium spp. and less activity against Aspergillus niger. Acremonium was very sensitive to both ethanol and methanol extracts of Acacia ampliceps stem-bark in both concentrations i.e. $1000 \mu \mathrm{g} / \mathrm{mL}$ and $500 \mu \mathrm{g} / \mathrm{mL}$. But methanol extract showed significant results than that of ethanol. It was noted that ZOI was directly proportional to the concentration of the extract applied i.e. high for 1000 $\mu \mathrm{g} / \mathrm{mL}$ and low for $500 \mu \mathrm{g} / \mathrm{mL}$. Zone of inhibition of standard drug Nystatin was higher than the extracts. At $1000 \mu \mathrm{g} / \mathrm{mL}$, ethanol and methanol showed ZOI of $16 \mathrm{~mm}$ and $20 \mathrm{~mm}$ while ZOI at $500 \mu \mathrm{g} / \mathrm{mL}$ was recorded to be $12 \mathrm{~mm}$ and $16 \mathrm{~mm}$ respectively. Zone of inhibition of Nystatin was recorded to be $22 \mathrm{~mm}$. Aspergillus niger was very sensitive to both ethanol and methanol extracts of Acacia ampliceps stem-bark and showed the same results at both concentrations i.e. $1000 \mu \mathrm{g} / \mathrm{mL}$ and 500 $\mu \mathrm{g} / \mathrm{mL}$. Zone of inhibition of Nystatin was higher than that of the applied extracts at both concentrations. At $1000 \mu \mathrm{g} / \mathrm{mL}$ as well as $500 \mu \mathrm{g} / \mathrm{ml}$, ethanol and methanol showed the same ZOI of $16 \mathrm{~mm}$ and $14 \mathrm{~mm}$ respectively. Zone of inhibition of $0.05 \%$ Nystatin was recorded to be $18 \mathrm{~mm}$. Rhizopus spp. was very sensitive to both ethanol and methanol extracts of Acacia ampliceps stem bark at both concentrations i.e. $1000 \mu \mathrm{g} / \mathrm{mL}$ and 500 $\mu \mathrm{g} / \mathrm{mL}$. Methanol showed significant results than ethanol. Zone of inhibition of methanol at high concentration $(1000 \mu \mathrm{g} / \mathrm{mL})$ is the same as that of standard drug (Nystatin). Zone of inhibition at low concentration (500 $\mu \mathrm{g} / \mathrm{mL}$ ) of both extracts were same and lower than that of Nystatin. Methanol at 1000 $\mu \mathrm{g} / \mathrm{ml}$, exhibited a ZOI of $20 \mathrm{~mm}$ which equal to that of Nystatin and that of ethanol is measured to $16 \mathrm{~mm}$. At $500 \mu \mathrm{g} / \mathrm{ml}$, ethanol and methanol showed the same ZOI of $14 \mathrm{~mm}$. Trichoderma spp. was very sensitive to both ethanol and methanol extracts of Acacia ampliceps Maslin stem-bark at both concentrations i.e. $1000 \mu \mathrm{g} / \mathrm{mL}$ and 500 $\mu \mathrm{g} / \mathrm{ml}$. Zone of inhibition was directly proportional to the concentration of the extract applied i.e. high for $1000 \mu \mathrm{g} / \mathrm{ml}$ and low for $500 \mu \mathrm{g} / \mathrm{ml}$. Methanol showed significant results than ethanol. Zone of inhibition of the standard drug (Nystatin) was higher than both extracts. Methanol at 1000 $\mu \mathrm{g} / \mathrm{mL}$, exhibited a ZOI of $20 \mathrm{~mm}$ which equal to that of Nystatin and that of ethanol is measured to $16 \mathrm{~mm}$. At $500 \mu \mathrm{g} / \mathrm{mL}$, ethanol and methanol showed the same ZOI of $14 \mathrm{~mm}$ (Table 1; Fig. $1 \&$ 2).

\section{Discussion}

Adversative side effects of antibiotics are known to cause some unusual serious infections, which enforced researchers to discover new cradles of effective antimicrobial medications. For this tenacity, plants have been analyzed for safe antimicrobial constituents which are proved to be a latent source of novel compounds of known constructive features [13-15]. A widespread array of therapeutic plant parts is used for extracts as raw drugs and they retain various medicinal physical characteristics. The different parts used are stem, flower, root, leaves, twigs exudates, fruit and modified plant organs. While some of these raw drugs are collected in lesser quantities by the native people and folk healers for indigenous used, many other raw drugs are collected in greater quantities and traded in 
the market as the raw material for many herbal pharmaceuticals [16].

Herbal medicines are nowadays regarded as the greatest substitute of antibiotics with no or very less side effects [17]. The use of active phytochemicals, in combination with antibiotics could elude the advent of resistant variants that might otherwise arise during treatment. These blends are likely to exert a synergistic effect or to lessen likely adverse side effects [18]. Though numerous plant species have been tested for their antimicrobial potential, majority of them have not been professionally estimated [19]. Due to the presence of effective antimycotic agents, and the advent of resistant or multiresistant strains, a permanent search and development of new drugs is desired [20]. The valuable remedial properties of plant materials normally result due to the secondary metabolites present in the plant although, it is usually not credited to a solo compound but a mix of different metabolites. The therapeutic actions of plants are unique to a specific plant species or group, consistent with the concept that the amalgamation of secondary products in a particular plant is taxonomically distinct [21].
A lot of work has been done on the antifungal potential of Acacia spp.[22] conducted an experiment to analyze the pharmacological activity of the ethyl acetate and ethanol extract of Acacia nilotica and Turnera subulata for its antifungal activity against six different fungal isolates namely, Aspergillus niger, Aspergillus flavus, Aspergillus fumigatus, Candida glabrata, Candida albicans and Penicillium chrysogenum. In the study of [23], ethanol, acetone and hexane roots extracts of Acacia catechu was resistant to Aspergillus niger, Fusarium oxysporum, Alternaria alternata, Rhizopus stolonifer and Macrophoma phaseolina. [24] reported that Acacia nilotica bark and leaf extract showed antifungal activity with $12 \mathrm{~mm}$ ZOI against Aspergillus flavus. [25] tested the ethanol extract of heartwood of Acacia catechu for antimycotic potential against Aspergillus niger, Aspergillus fumigate, Candida albicans, Mucor spp. and Penicillium marneffe. In the study of [26], Acacia nilotica and Acacia catechu were most promising species. Both exhibited strong activity against two fungal species (Aspergillus niger and Candida albicans).

Table 1. Antifungal activity of ethanol and methanol extracts of stem-bark of Acacia ampliceps Maslin

\begin{tabular}{|c|c|c|c|c|c|c|c|}
\hline \multirow{4}{*}{ S/No. } & \multirow{4}{*}{ Fungal strains } & \multicolumn{6}{|c|}{ Concentration of the extracts $(\mu \mathrm{g} / \mathrm{mL})$} \\
\hline & & \multicolumn{2}{|c|}{ Ethanol } & \multicolumn{2}{|c|}{ Methanol } & \multicolumn{2}{|c|}{ Standard control } \\
\hline & & $1000 \mu \mathrm{g} / \mathrm{mL}$ & $500 \mu \mathrm{g} / \mathrm{mL}$ & $1000 \mu \mathrm{g} / \mathrm{mL}$ & $500 \mu \mathrm{g} / \mathrm{mL}$ & $\begin{array}{c}\text { Nystatin } \\
\text { (+ive) } \\
\text { control) }\end{array}$ & $\begin{array}{c}\text { DMSO } \\
\text { (-ive) }\end{array}$ \\
\hline & & \multicolumn{6}{|c|}{ Zone of inhibition (mm) } \\
\hline 1 & Acremonium spp. & 16 & 12 & 20 & 16 & 22 & - \\
\hline 2 & Aspergillus niger & 16 & 14 & 16 & 14 & 18 & - \\
\hline 3 & Rhizopus spp. & 16 & 14 & 20 & 14 & 20 & - \\
\hline 4 & Trichoderma & 18 & 14 & 22 & 16 & 23 & - \\
\hline
\end{tabular}




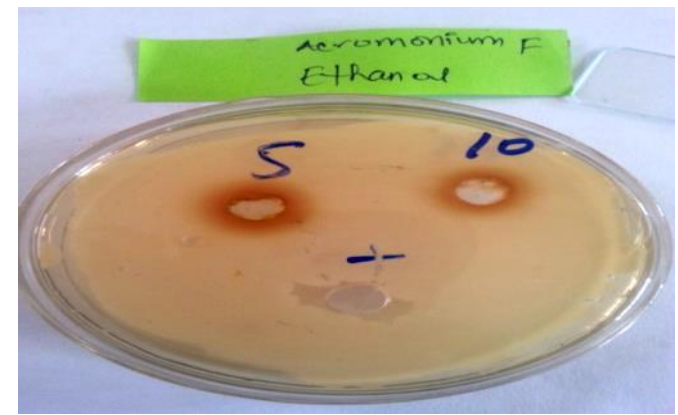

1. Acremonium spp. (ethanol)

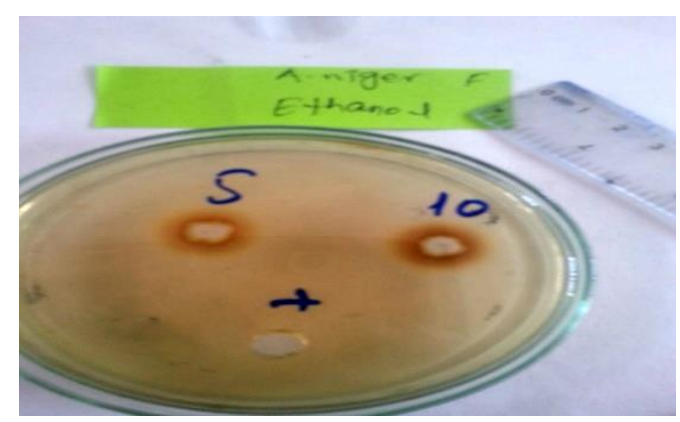

3. Aspergillus niger (ethanol)

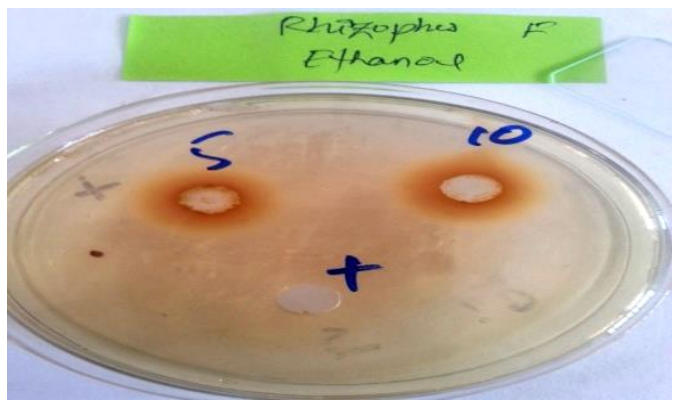

5. Rhizopus spp. (ethanol)

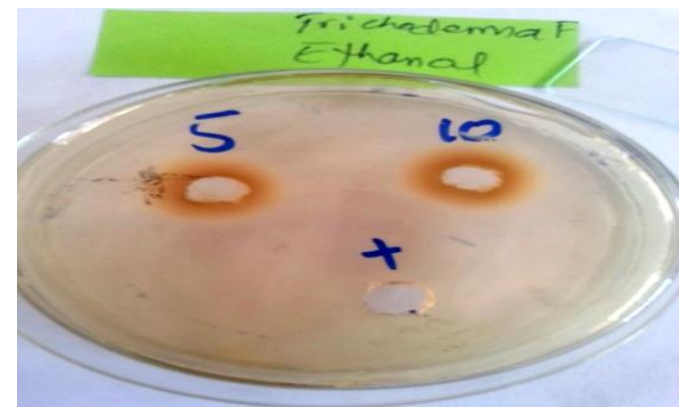

7. Trichoderma spp. (ethanol)

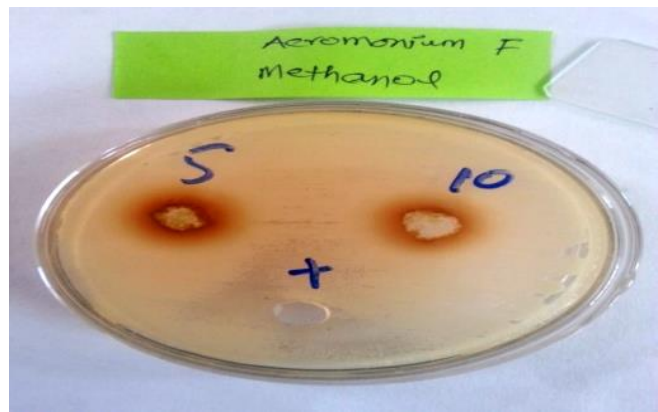

2. Acremonium spp. (methanol)

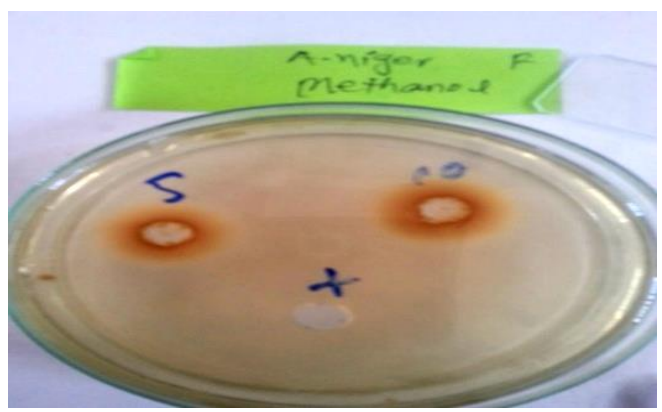

4. Aspergillus niger (methanol)

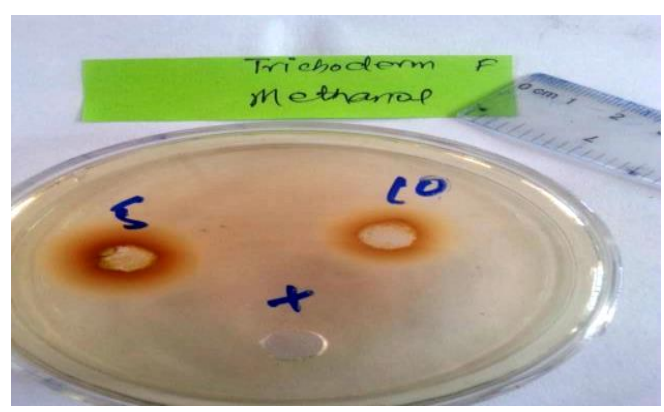

6. Rhizopus spp. (methanol)

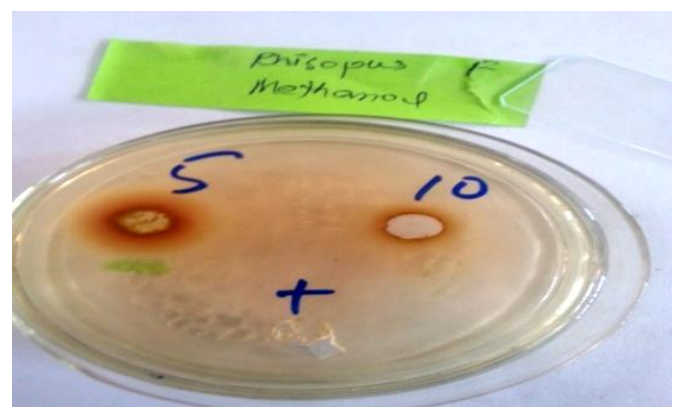

8. Trichderma spp. (methanol)

Figure 1. Antifungal activity of ethanol and methanol extracted samples of Acacia ampliceps against fungal strains 


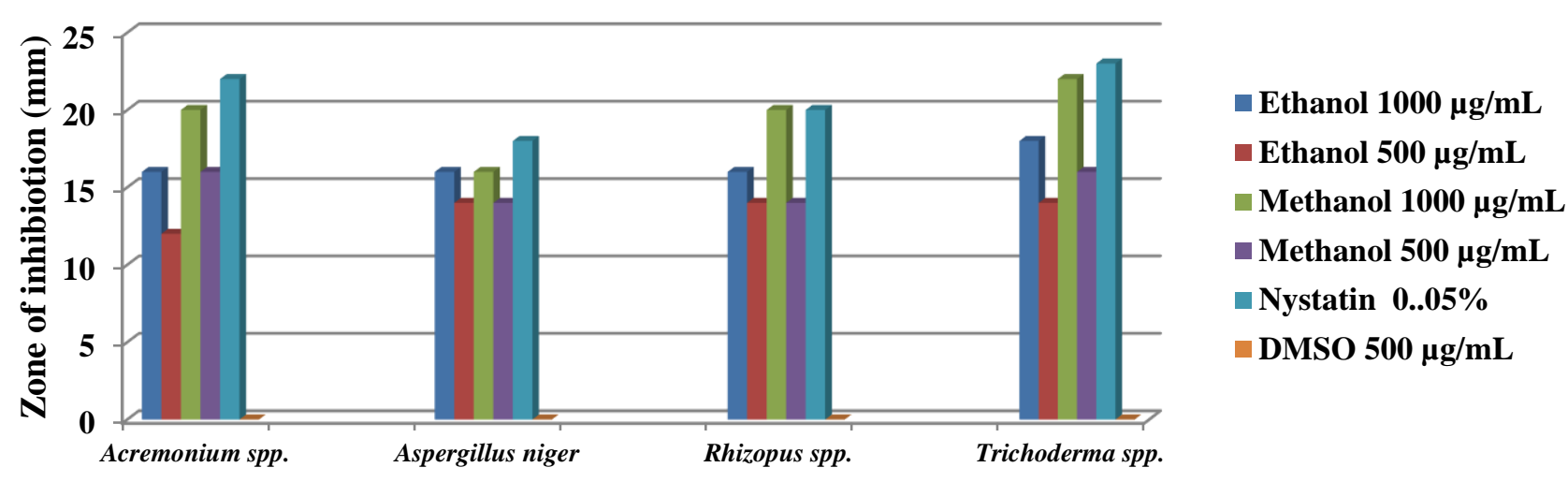

Fungal strains

Figure 2. Zone of inhibition of ethanol and methanol extracts of Acacia ampliceps stem bark as compared to standard antibiotic (Nystatin) against four fungal strains

Abd-Ulgadir et al. [27] observed the antimicrobial effect of aqueous and methanolic extract of stem and leaves of Acacia nilotica on five species of bacteria i.e. Escherichia coli (ATCC 25922), Klebsiella pneumonia (ATCC 53657), Proteus vulgaris (ATCC 6380), Staphylococcus aureus (ATCC 25933) and Pseudomonas aeruginosa (ATCC 27853) and one fungi species Candida albicans (ATCC 7596) by agar well diffusion method. Both methanolic and aqueous extracts showed strong antimicrobial activity [28] tested the aqueous extract of 52 plants from various families for their antifungal activity against eight significant species of Aspergillus such as Aspergillus ochraceus, Aspergillus columnaris, Aspergillus fumigatus Aspergillus flavipes, Aspergillus candidus, Aspergillus flavus, Aspergillus niger and Aspergillus tamarii. Among these tested plants, aqueous extract of Acacia nilotica showed noteworthy antifungal activity against the Aspergillus species. Antifungal activity of the water extraxt of the flower of Acacia Saligna (Labill.) was evaluated by [29] in micro-dilution method against three mold fungi; Fusarium culmorum MH352452,Rhizoctonia solani MH352450, and Penicillium chrysogenum MH352451 that cause root rot, cankers, and green fruit rot, respectively, and it was concluded that by increasing the extract concentration, the percentage inhibition of fungal mycelial was significantly improved as compared to the control treatment, particularly against $P$. chrysogenum, suggesting that the use of $A$. saligna flower extract as a wood biopreservative inhibited the growth of molds that cause discoloration of wood and wood merchandises.

\section{Conclusion}

Two different extracts i.e. ethanol and methanol of the stem-bark of Acacia ampliceps were used against four fungal strains. It was concluded that methanol extract was comparatively inhibitory to all fungal strains than ethanol extract.

\section{Authors' contributions}

Conceived and designed the experiments: MS Khan, Performed the experiments: Fatima, Analysed the data: MA Sajad, Contributed materials/ analysis/ tools: S Rahman, Wrote the paper: M Anwar. 


\section{Acknowledgement}

The authors are deeply grateful to the Department of Botany, Islamia College Peshawar, for their consistent help, support and for providing adequate laboratory facilities to carry out the research work.

\section{References}

1. Alviano DS \& Alvaino CS (2009). Plant extracts: search for new alternatives to treat microbial diseases. Curr Pharm Biotech 10: 106-121.

2. Zhang R, Eggleston K, Rotimi V \& Zeckhauser RJ (2006). Antibiotic resistance as a global threat: evidence from China, Kuwait and the United States. Glob Health 2: 6.

3. Malini M, Abirami G, Hemalatha V \& Annadurai G (2013). Antimicrobial activity of ethanolic and aqueous extracts of medicinal plants against waste water pathogens. Inter J Res Pure Appl Microbio 3: 40-42.

4. Dorman HJ \& Deans SG (2000). Antimicrobial agents from plants: antibacterial activity of plant volatile oils. J Appl Microbio 88: 308-316.

5. Talib WH \& Mahasneh AM (2010). Antimicrobial, cytotoxicity and phytochemical screening of Jordanian plants used in traditional medicine. $\mathrm{Mol}$ 15: 1811-1824.

6. Ajaib M, Khan ZUD, Khan NU, Abbasi MA, Shahwar D, Wahab M \& Saddiqui MF (2011). Antibacterial and antioxidant activities of an ethnobotanically important plant sauromatum Venosum (ait.) Schott of district Kotli, Azad Jammu \& Kashmir. Pak J Bot 43(1): 579-585.

7. Farombi EO (2003). African indigenous plants with chemotherapeutic potentials and biotechnological approach to the production of bioactive prophylactic agents. $A J B$ 2: 662-671.
8. Seigler DS (2003). Phytochemistry of Acacia-sensu lato. Biochem. Syst Ecol 31(8): 845-873.

9. The Plant List (2013). Version 1.1. Published on the Internet; http://www.theplantlist.org/ (accessed 1st January).

10. Uddin G, Rauf A, Siddiqui BS \& Shah SQ (2011). Preliminary Comparative phytochemicals Spectrum Books Ltd, Ibadan. 2: 288.

11. Parekh J \& Chanda S (2006). In-vitro Antimicrobial activities of extracts of Launaea procumbens Roxb. (Labiateae), Vitis vinifera L. (Vitaceae) and Cyperus rotundus L. (cyperaceae). Afric J Biomed Res 89-93.

12. Bupesh G, Amutha C, Nandagopal S, Ganeshkumar A, Sureshkumar P \& Murali KS (2007). Antibacterial activity of Mentha piperita L (Peppermint) from leaf extracts- a medicnal plant. Acta Agri Sloven 73-79.

13. Maurer-Grimes B, Mcbeth DL, Hallihan B \& Delph S (1996). Antimicrobial activity in medicinal plants of the Scrophulariaceae and Acanthaceae. Int J Pharmaco 34: 243-248.

14. Rabe $\mathrm{T} \&$ Van-Staden J (1997). Antibacterial activity of South African plants used for medicinal purposes. $J$ Ethnopharm 56: 81-87.

15. Marchese A \& Shito GC (2001). Resistance patterns of lower respiratory tract pathogens in Europe. Inter $J$ Antimic Agents 16: 25-29.

16. Uniyal SK, Singh KN, Jamwal P \& Lal (2006).Traditional use of medicinal plants among the tribal communities of Chhota Bhangal, Western Himalayan. $J$ Ethnobiol Ethnomed 2: 1-14.

17. Sofowora LA. 1993. Medicinal plants and traditional medicine. Spectrum books Ltd. Ibadan, Nigeria. 224-227.

18. Abreu AC, Tavares RR, Borges A, Mergulhao F \& Simoes M (2013). 
Current and emergent strategies for disinfection of hospital environments. $J$ Antimicrob Chemother 68: 2718-2732.

19. Balandrin MF, Klocke JA, Wurtele ES, \& Bollinger WH (1985). Natural plant chemicals: Sources of Industrial and Medicinal materials. Sci 228: 11541160.

20. Schmourlo G. Mendonça-Filho RR, Alviano CS, \& Costa SS (2005). Screening of Antifungal Agents Using Ethanol Precipitation and Bioautography of Medicinal and Food Plants. $J$ Ethnopharm 96: 563-568.

21. Parekh J, Jadeja D \& Chanda S (2005). Efficacy of Aqueous and Methanol Extracts of Some Medicinal Plants for Potential Antibacterial Activity. Turk J Biol 29: 203-210.

22. Prabhahar C, Saleshrani K, Saranraj P \& Tharmaraj K (2012). Studies on the antifungal activity of Turnera subulata and Acacia nilotica against selected fungal pathogens. IJRSR 3(3): 149-154.

23. Nagaraja TG, Sarang SV \& Jambhale DC (2008). Evaluation of anti-mycotic activity of Acacia catechu Willd. (Mimosaceae). J Biopest 1(2):197-198.

24. Mahesh B \& Satish S (2008). Antimicrobial Activity of Some Important Medicinal Plant against Plant and Human Pathogens. World J Agric Sci 4 (S): 839-843.

25. Roy A, Geetha RV \& Geetha T (2011). In vitro Evaluation of Anti-mycotic activity of Heartwood Extract of Acacia catechu Willd. J Pharm Res 4(7): 201011.

26. Saini ML, Saini R, Roy S \& Kumar A (2008). Comparitive pharmacognostical and antimicrobial studies of Acacia species (Mimosaceae). JMPR 2(12): 378-386.

27. Abd-Ulgadir KS, El- Rofaei NA \& ElKamali HH (2014). Antimicrobial property of Acacia nilotica spp. against some causative agent of urogenital infections. WJPR 4(3): 34-45.

28. Satish S, Mohana DC, Ranhavendra MP \& Raveesha KA (2007). Antifungal activity of some plant extracts against important seed borne pathogens of Aspergillus sp. J Agric Tech 3(1): 109119.

29. Al-Huqail AA, Said IB, Mohamed ZMS, Hayssam MA, Manzer HS \& Abdelfattah ZMS (2019.). Antifungal, Antibacterial, and Antioxidant Activities of Acacia Saligna (Labill.) H.L.Wendl.Flower Extract: HPLC Analysis of Phenolic and Flavonoid Compounds. Mol 24: 700. 